\title{
Serotyping and the Dienes reaction on Proteus mirabilis from hospital infections
}

\author{
J. de LOUVOIS'
}

From the Department of Pathology, Midland Centre for Neurosurgery and Neurology, Holly Lane, Smethwick, Warley, Worcs.

SYNOPSIS The serotype of 320 strains of Proteus mirabilis from clinical material was determined. Using $20 \mathrm{O}$ antisera and four $\mathrm{H}$ antisera $61 \%$ of strains could be fully identified and $90 \%$ partially identified. A large number of serotypes were recognized but no difference was found between the serotype of organisms infecting the urinary tract and those from other infections. Biochemically identical organisms found in the same ward generally differed in serology. Proteus mirabilis was isolated from the faeces of $84.5 \%$ of 84 patients with urinary infection and from none of 20 normal controls. By serology and the Dienes test $61 \%$ of the organisms isolated from the urine and faeces of a single patient were identical, indicating that infection arose from the intestine.

Most groups of serologically identical strains could, by the Dienes test, be further divided into a number of subtypes indicating that the strains were different and that cross infection had not been responsible for their spread. With three serological groups, however, the majority of strains belonged to a single Dienes type and it was concluded that these organisms had been spread from a common reservoir or carrier.

Because of the unreliability of the Dienes test when carried out on random organisms it is suggested that reliable results can only be obtained by combining the Dienes test with serotyping.

Because of their importance as causes of hospital infection (Finland, 1960; McCabe and Jackson, 1962) and the desirability, from the epidemiological viewpoint, of being able to identify bacterial strains within a species, Gram-negative bacilli have received increasing attention in recent years. Esch. coli (Ujváry 1958; Turck and Petersdorf 1962; Percival, Brumfitt, and de Louvois, 1964), Klebsiella species (Kauffmann, 1949; Brooke, 1951; Edwards and Fife, 1952, 1955), and especially Pseudomonas species (Habs, 1957; Ayliffe, Lowbury, Hamilton, Small, Asheshov, and Parker, 1965; Wahba, 1965; Gillies and Govan, 1966), have all been studied and, by phage or colicine typing, or serology, valuable information on the distribution and epidemiology of these organisms has been obtained.

In spite of the fact that Proteus mirabilis infections often present serious clinical and epidemiological problems this species has so far received little attention. Proteus vulgaris and Proteus mirabilis

\footnotetext{
'1Present address: Department of Pathology, Edgware General Hospital, Edgware, Middlesex.

Received for publication 8 August 1968.
}

(Hauser, 1885) were shown by Kauffmann and Perch (1947) to be members of the same antigenic group in spite of being biochemically distinct. Further work on the general bacteriology of these species (Cook, 1948; Elek, 1948; Barber and Waterworth, 1964; Huang, 1966) added to the general information but did not assist in the identification of strains.

Studies by Kippax (1957) on atypical biochemical types, by Belyavin (1951), Krikler (1953), and Story (1954) on the Dienes reaction, and by Pavlatou, Hassikou-Kaklamani, and Zamkioti (1965) and France and Markham (1968) on typing by the use of bacteriophage have attempted to differentiate strains on non-serological grounds.

Following the publication by Perch (1948) of an extended antigenic scheme for Proteus mirabilis and Proteus vulgaris the only study using this scheme to identify strains isolated from clinical material serologically was by Lányi (1956) in Hungary. In Britain the only serological studies have been by Belyavin, Miles, and Miles (1951) and Krikler (1953) and both used random organisms as their standard strains 
which were not fully investigated antigenically and which are no longer available.

The present study sets out to examine serologically strains of Proteus mirabilis from clinical material using the standard organisms of Perch. The clinical strains were isolated from patients who had infections of the urinary tract or infected wounds, and from the faeces of patients with infections of the urinary tract. The objects were to determine the serology of the infecting strains isolated, to establish any serological difference between strains infecting the urinary tract and those infecting wounds, to determine whether patients with urinary tract infections carried organisms of the same serotype in their faeces, and to attempt to recognize any reservoirs of cross infection.

Dienes $(1946,1947)$ suggested that strains that gave no line of demarcation when swarming together were identical while those that gave a demarcation line were not identical but further studies (Krikler, 1953; Story, 1954) have cast doubt on this assumption. Because the Dienes test is at present the only readily available means of examining strains epidemiologically it was performed on groups of organisms to determine the reliability of the test for recognizing identical strains and to assess its value as a means of dividing strains within a serotype.

\section{MATERIALS AND METHODS}

ORGANISMS Three hundred and ninety-one strains of Proteus mirabilis isolated from clinical material were investigated. Of these, 218 were from patients with diagnosed urinary tract infection, 102 from patients with other infections, and 71 from the faeces of patients with urinary tract infection. The specimens of faeces were collected two days after the appropriate antibiotic therapy had begun, in order to eliminate contamination.

o ANTISERA From the antigenic scheme of Perch, organisms of cultural type 2 , ie, Proteus mirabilis, were selected from the first $30 \mathrm{O}$ types and the following $\mathrm{O}$ antisera were prepared: $\mathrm{O}_{3}, \mathrm{O}_{5}, \mathrm{O}_{6}, \mathrm{O}_{7}, \mathrm{Q}_{9}, \mathrm{O}_{10}, \mathrm{O}_{11}, \mathrm{O}_{13}$, $\mathrm{O}_{14}, \mathrm{O}_{16}, \mathrm{O}_{17}, \mathrm{O}_{18}, \mathrm{O}_{19}, \mathrm{O}_{20}, \mathrm{O}_{23}, \mathrm{O}_{24}, \mathrm{O}_{26}, \mathrm{O}_{28}, \mathrm{O}_{29}, \mathrm{O}_{30}$. These sera were manufactured by injecting rabbits with a series of increasing doses of b.cterial $O$ antigen, prepared from the standard strains. The specific and nonspecific $\mathbf{O}$ antibody titres of the sera were determined by a simple doubling dilution-bacterial agglutination technique and the sera diluted or absorbed, as necessary, to render them specific.

H ANTISERA. H Antisera were prepared against organisms possessing $\mathrm{H}_{1}, \mathrm{H}_{2}, \mathrm{H}_{3}$, and $\mathrm{H}_{4}$ antigens, these organisms being selected from the standard strains. Formolized six-hour broth cultures were injected into rabbits using a similar method as that for the preparation of $\mathrm{O}$ antisera. Dilutions of $\mathbf{H}$ antisera were tested on a glass tile against saline suspensions, prepared from swarming cultures on blood agar, of the homologous strain. Cross-reactions could be diluted out leaving a serum that gave rapi产 macroscopic agglutination with the homologous organ-: ism.

EXAMINATION OF STRAINS All organisms were first identified as $\operatorname{Pr}$. mirabilis by biochemical reactions, an were then stored at $4^{\circ} \mathrm{C}$ on solid media until required.

$O$ antigenic suspensions were prepared to each strai $\mathbb{\Phi}^{\infty}$ by heating saline suspensions of washed overnight brotty cultures at $105^{\circ} \mathrm{C}$ for one hour. These were preserved with formalin and stored at $4^{\circ} \mathrm{C}$.

TYPING PROCEDURE The bacterial $O$ antigen of the tes organism was diluted in saline to give an optical density of 0.35 to 0.40 at wavelength $480 \mathrm{~m} \mu$ and a path width of $1 \mathrm{~cm}$. Of this dilution, $0 \cdot 1 \mathrm{ml}$ was incubated at $50^{\circ} \mathrm{C}$ fo 18 hours with $0.1 \mathrm{ml}$ of each specific $O$ antiserum. Afteci being allowed to stand for one hour at room temperaturi each tube was examined for agglutination. A saline controd was included to recognize autoagglutinating strains.

AUTOAGglutinating strains When a heat-killed $\vec{Q}$ antigen was found to be autoagglutinable, an alcoholig antigen from a desoxycholate citrate agar culture was. prepared. Strains found to be autoagglutinable after thifo procedure were not investigated further.

H SEROTYPE Organisms for $\mathbf{H}$ typing were subculture onto blood agar plates. After overnight incubation saline suspensions were prepared from the swarming portions of each growth. Drops of each bacterial suspension were mixed with drops of specific $\mathbf{H}$ antiserum on a glass tile and examined for agglutination after rocking for half minute.

DIENES TEST Strains of Proteus mirabilis to be examine for the Dienes reaction were stab inoculated onte opposite sides of an agar plate and the swarming growtio was examined after 18 hours' incubation for a line of demarcation where the two cultures met. The Dienes reaction is negative when strains swarm into each other imperceptibly and positive when a line of demarcation can be seen where they meet.

To determine the reliability of the test for recognizing identical strains a panel of 41 serologically identified organisms was examined. Each organism was teste. against the other 40, a total of 800 tests. Pairs of organ isms from the urine and faeces of the same patient were also examined to determine the rate of autoinfection. In addition groups of serologically identical strains wer尺 examined to assess the value of the Dienes test for furthef division of organisms within a serotype, and as a possible means of recognizing cases of cross infection. All straing that were Dienes negative were re-examined three or foun times for confirmation.

\section{RESULTS}

The $O$ antisera produced all had titres of $1 / 10,000$ t $1 / 20,000$ when tested with the standard antigen at an optical density of 0.35 to 0.40 . In the majority of cases non-specific reactions were less than 1/640 an 
so could be diluted out while still leaving a highly reactive specific serum. However, cross reactions between four sera were higher than 1/640 and the sera had, therefore, to be absorbed.

The $\mathrm{H}$ antisera produced all reacted rapidly on the tile at dilutions of $1 / 500$. Their respective $\mathrm{O}$ agglutinins were all below $1 / 300$ in titre.

SEROTYPES OF THE 320 STRAINS ISOLATED FROM INFECTIONS Using the $20 \mathrm{O}$ antisera prepared, 197 $(61 \%)$ of the organisms studied were $\mathrm{O}$ typable, while with the four $\mathrm{H}$ antisera $287(90 \%)$ of organisms could be recognized. The 197 serotyped organisms could be divided into 49 serotypes by their $\mathrm{O}$ and $\mathrm{H}$ antigens.

Of the 49 serotypes found, nine, involving 21 strains $(11 \%)$, had not previously been described. These were $\mathrm{O}_{6} \mathrm{H}-, \mathrm{O}_{16} \mathrm{H}_{2}, \mathrm{O}_{17} \mathrm{H}_{2}, \mathrm{O}_{17} \mathrm{H}_{3}, \mathrm{O}_{17} \mathrm{H}-$, $\mathrm{O}_{26} \mathrm{H}_{1}, \mathrm{O}_{26} \mathrm{H}$ -, $\mathrm{O}_{28} \mathrm{H}_{1}$, and $\mathrm{O}_{29} \mathrm{H}_{1}, \mathrm{H}$ - denoting an $\mathrm{H}$ antigen other than $\mathrm{H}_{1}, \mathrm{H}_{2}, \mathrm{H}_{3}$, or $\mathrm{H}_{4}$. The remaining 123 strains did not have typable $\mathrm{O}$ antigens but could be divided into five groups by their $\mathbf{H}$ antigens. Three of these strains were autoagglutinable.

The distribution of $\mathbf{O}$ types among organisms isolated from urinary tract and wound infections is shown in Table I. Table I shows that there is no significant difference between the $O$ types infecting wounds and those infecting the urinary tract. In both groups certain serotypes, notably $\mathrm{O}_{3}, \mathrm{O}_{10}$, $\mathrm{O}_{13}$, and $\mathrm{O}_{26}$, occurred more frequently than others. Comparison between the serotype of the organisms and the ward from which they were isolated showed no significant relationship. In only $22 \%$ of cases did a particular serotype occur more than once in any one ward.

PROTEUS STRAINS ISOLATED FROM THE FAECES OF PATIENTS WITH PROTEUS URINARY TRACT INFECTIONS Proteus mirabilis was isolated from the faeces of 71 $(84.5 \%)$ of 84 patients with Proteus mirabilis urinary tract infection and was not isolated from any of 20 uninfected control patients. The distribution of $\mathbf{O}$ types among these organisms is shown in Table $I$. These organisms show the same distribution of $\mathbf{O}$ types as those found in infections. Forty-seven of these 71 strains came from patients with typable organisms in their urine and of these $33(70 \%)$ showed identical organisms in both urine and faeces (Table II). Of the remaining 24 patients nine had organisms of non-groupable $\mathrm{O}$ type but identical $\mathrm{H}$

TABLE I

\begin{tabular}{|c|c|c|c|}
\hline \multirow[b]{2}{*}{ O Type } & \multicolumn{3}{|c|}{ DISTRIBUTION OF GROUPABLE 'O’'TYPES FROM THREE SOURCES } \\
\hline & Urine & Wounds & Faeces \\
\hline $\begin{array}{l}O_{3} \\
O_{6} \\
O_{6} \\
O_{7} \\
O_{9} \\
O_{10} \\
O_{11} \\
O_{13} \\
O_{16} \\
O_{17} \\
O_{18} \\
O_{20} \\
O_{23} \\
O_{24} \\
O_{28} \\
O_{28} \\
O_{23} \\
O_{30}\end{array}$ & $\begin{array}{r}24(18.0 \%) \\
1(0.8 \%) \\
11(8.3 \%) \\
1(0.8 \%) \\
2(1.5 \%) \\
17(12.8 \%) \\
6(4 \cdot 4 \%) \\
12(9.0 \%) \\
4(3.0 \%) \\
4(3.0 \%) \\
1(0.8 \%) \\
3(2.3 \%) \\
10(7.5 \%) \\
2(1.5 \%) \\
10(7.5 \%) \\
12(9.0 \%) \\
3(2 \cdot 3 \%) \\
10(7.5 \%)\end{array}$ & $\begin{array}{l}16(25 \cdot 0 \%) \\
0 \\
2(3 \cdot 1 \%) \\
0 \\
0 \\
8(12 \cdot 5 \%) \\
0 \\
6(9 \cdot 3 \%) \\
0 \\
3(4 \cdot 7 \%) \\
0 \\
2(3 \cdot 1 \%) \\
3(4 \cdot 7 \%) \\
6(9 \cdot 3 \%) \\
4(6 \cdot 3 \%) \\
3(4 \cdot 7 \%) \\
4(6 \cdot 3 \%) \\
7(11 \cdot 0 \%)\end{array}$ & $\begin{array}{l}9(19.0 \%) \\
1(2 \cdot 2 \%) \\
2(4 \cdot 3 \%) \\
0 \\
1(2 \cdot 2 \%) \\
9(19.0 \%) \\
1(2 \cdot 2 \%) \\
4(8.5 \%) \\
2(4 \cdot 3 \%) \\
0 \\
1(2 \cdot 2 \%) \\
0 \\
2(4 \cdot 3 \%) \\
0 \\
4(8.5 \%) \\
6(12.6 \%) \\
4(8.5 \%) \\
1(2.2 \%)\end{array}$ \\
\hline $\begin{array}{l}\text { Total groupable } \\
\text { Not groupable } \\
\text { Autoagglutinable }\end{array}$ & $\begin{array}{r}133 \\
82 \\
3\end{array}$ & $\begin{array}{r}64 \\
38 \\
0\end{array}$ & $\begin{array}{r}47 \\
23 \\
1\end{array}$ \\
\hline Total & 218 & 102 & 71 \\
\hline
\end{tabular}

TABLE II

SEROLOGY OF STRAINS FROM URINE AND FAECES OF INFECTED PATIENTS

\begin{tabular}{lccc} 
Urinary Organisms & $\begin{array}{l}\text { No. of } \\
\text { Cases }\end{array}$ & $\begin{array}{l}\text { Identical Serotype } \\
\text { in Faeces }\end{array}$ & $\begin{array}{l}\text { Different Serotype } \\
\text { in Faeces }\end{array}$ \\
\hline Typeable strains & 54 & $33(70 \%)$ & 14 \\
O Non-typeable strains & 28 & 91 & 13 \\
Autoagglutinable strains & 2 & 1 & 1
\end{tabular}

${ }^{1}$ Possibly identical 
TABLE III

\begin{tabular}{|c|c|c|c|c|}
\hline \multirow{3}{*}{$\begin{array}{l}\text { No. of } \\
\text { Tests } \\
\text { Performed }\end{array}$} & \multicolumn{3}{|c|}{ DIENES TEST ON 41 SEROLOGICALLY IDENTIFIED STRAINS } & \\
\hline & \multirow{2}{*}{$\begin{array}{l}\text { Pairs } 0 . \\
\text { Dienes- } \\
\text { Negative } \\
\text { Organisms }\end{array}$} & \multicolumn{3}{|c|}{ Dienes Test Negative 'Pairs' } \\
\hline & & $\begin{array}{l}\text { Serologically } \\
\text { Identical }\end{array}$ & $\begin{array}{l}\text { Different } O \text { Antigen and } \\
\text { Identical } H \text { Antigen }\end{array}$ & $\begin{array}{l}\text { Serologically } \\
\text { Distinct }\end{array}$ \\
\hline \multirow[t]{3}{*}{800} & 16 & 11 & 4 & 1 \\
\hline & \multirow{2}{*}{\multicolumn{4}{|c|}{ TABLE IV }} \\
\hline & & & & \\
\hline \multirow{2}{*}{ Serology } & \multirow{2}{*}{ Total } & \multicolumn{2}{|c|}{ Dienes Test } & \\
\hline & & \multicolumn{2}{|c|}{$\begin{array}{l}\text { Positive } \\
\text { (Line of Demarcation) }\end{array}$} & of Demarcation) \\
\hline
\end{tabular}

\begin{tabular}{|c|c|c|c|}
\hline Serotyped Pairs & & & \\
\hline Pairs identical & 32 & 1 & 31 \\
\hline Pairs different & 19 & 10 & 9 \\
\hline O Non-groupable Strains & & & \\
\hline With identical $\mathbf{H}$ antigen & 9 & 1 & 8 \\
\hline With different $\mathbf{H}$ antigen & 3 & 0 & 3 \\
\hline O Autoagglutinable Strains & & & \\
\hline $\begin{array}{l}\text { With different } \mathrm{H} \text { antigen } \\
\text { One or both strains non-motile } \\
\text { Total }\end{array}$ & $\begin{array}{r}2 \\
6 \\
71\end{array}$ & 1 & 1 \\
\hline
\end{tabular}

type in both their urine and faeces. In a number of cases an organism of uncommon serotype was isolated from a patient's urine and faeces, thus discounting the possibility that urine and faeces had derived their organisms from separate sources.

A similar incidence of typable organisms was found in the urines of both men and women. In addition identical organisms were found in the faeces with similar frequency in both sexes.

DIENES TEST ON SEROLOGICALLY IDENTIFIED STRAINS When 41 serologically identified strains of Proteus mirabilis were examined only 16 pairs of organisms were repeatedly identical by the Dienes test. Eleven of these pairs were serologically identical. The organisms of the remaining five Dienes identical pairs were serologically distinct although in four of them the pairs shared a common $\mathbf{H}$ antigen (Table III).

DIENES TEST ON 'PAIRS' OF ORGANISMS FROM URINE AND FAECES The results of the Dienes test performed on the 'pairs' of Proteus mirabilis isolated from 71 patients are shown in Table IV. The majority of serologically identical pairs gave no line of demarcation by the Dienes test. Twelve serologically distinct pairs also gave no line of demarcation; however, eight of these pairs had common $\mathrm{H}$ antigens. There was also one pair of organisms that were biochemically and serologically identical but showed a line of demarcation between the swarming cultures.

DIENES TEST ON SEROLOGICALLY IDENTICAL STRAINS ISOLATED ON DIFFERENT WARDS The results of the Dienes test on organisms of the same serological group found in urinary tract infections are shown in
Table $\mathrm{V}$. With the exception of groups $\mathrm{O}_{3} \mathrm{H}_{1}$ ance $\mathrm{O}_{28} \mathrm{H}_{2}$ the number of Dienes types recognized is almost as large as the number of wards from which the organisms were isolated. In some cases sero-

\section{TABLE V}

RESULTS OF DIENES TEST ON SEROLOGICALLY IDENTICAL STRAINS FROM URINARY TRACT INFECTIONS IN DIFFERENT

\begin{tabular}{llll} 
Serotype & $\begin{array}{l}\text { No. of } \\
\text { Strains }\end{array}$ & $\begin{array}{l}\text { No. of } \\
\text { Different } \\
\text { Wards }\end{array}$ & $\begin{array}{l}\text { No. of } \\
\text { Dienes Types }\end{array}$ \\
\hline
\end{tabular}

\begin{tabular}{lrll}
\hline $\mathrm{O}_{3} \mathrm{H}_{1}$ & 10 & 5 & 2 \\
$\mathrm{O}_{3} \mathrm{H}_{2}$ & 12 & 7 & 7 \\
$\mathrm{O}_{10} \mathrm{H}_{1}$ & 6 & 2 & 3 \\
$\mathrm{O}_{10} \mathrm{H}_{2}$ & 6 & 3 & 4 \\
$\mathrm{O}_{23} \mathrm{H}_{2}$ & 6 & 3 & 4 \\
$\mathrm{O}_{28} \mathrm{H}_{2}$ & 6 & 5 & 3 \\
$\mathrm{O}_{38} \mathrm{H}_{2}$ & 7 & 5 & 1
\end{tabular}

logically identical organisms of the same Dienes type were found in a number of wards while in others two or more Dienes types were recognized amongst serologically identical organisms from a single ward In only half of the cases where two or more serologi- $\omega$ cally identical strains were isolated from the same ward was the Dienes test negative, indicating thate the strains were identical. The seven strains of $\mathrm{O}_{28} \mathrm{H}_{2}$ isolated came from widely spaced wards and ${ }^{+}$ were all, by the Dienes test, identical. Nine organ- ${ }^{2}$ isms belonging to group $\mathrm{O}_{3} \mathrm{H}_{1}$ were also apparently identical. This indicates that these infections arose? from persistent reservoirs or carriers.

The results of the Dienes test on groups of sero? logically identical strains from wound infections? 
shows the same distribution as that found with urinary organisms (Table VI). The majority of serological groups contained several Dienes types but the strains of $\mathrm{O}_{30} \mathrm{H}_{2}$ found on the three different wards were of identical Dienes type.

\section{TABLE VI}

RESULTS OF DIENES TEST OF SEROLOGICALLY IDENTICAL STRAINS FROM WOUND INFECTIONS IN DIFFERENT WARDS

\begin{tabular}{lccc} 
Serotype & $\begin{array}{l}\text { No. of } \\
\text { Strains }\end{array}$ & $\begin{array}{l}\text { No. of } \\
\text { Wards }\end{array}$ & $\begin{array}{l}\text { No. of } \\
\text { Dienes Types }\end{array}$ \\
\hline $\mathrm{O}_{3} \mathrm{H}_{1}$ & 12 & 5 & 5 \\
$\mathrm{O}_{3} \mathrm{H}_{2}$ & 6 & 5 & 3 \\
$\mathrm{O}_{10} \mathrm{H}_{1}$ & 5 & 3 & 4 \\
$\mathrm{O}_{30} \mathrm{H}_{2}$ & 5 & 3 & 1
\end{tabular}

\section{DISCUSSION}

The desirability of a method for identifying strains of Proteus mirabilis has long been recognized. Kauffmann and Perch (1947) published a limited antigenic scheme for Proteus hauseri (Pr. mirabilis and Pr. vulgaris) which was considerably extended by Perch (1948). Belyavin et al (1951) and Krikler (1953), using a limited number of strains, few of which had been antigenically classified, were the first workers in Britain to investigate serologically strains of Proteus mirabilis from clinical material. Unfortunately, their strains were not identified within Perch's scheme and are no longer available, thus preventing comparison between their work and any subsequent studies.

The only other serological investigation of this group of organisms was by Lányi (1956) in Hungary who examined 1,242 strains of Proteus, 1,041 of which were Proteus mirabilis. A large number of Lányi's strains came from cases of infantile enteritis that were not due to any recognized enteric pathogen. Amongst these cases Lányi found a significant increase in the rate of isolation of Proteus belonging to groups $\mathrm{O}_{3}$ and $\mathrm{O}_{26}$. Although these serotypes are fairly common the possibility that there are infantile enterites producing strains of Proteus similar to those of Esch. coli cannot be ruled out. It is perhaps only coincidence that the strains isolated from an outbreak of meningitis in infants at Queen Elizabeth Hospital, Birmingham (unpublished information), also belonged to group $\mathrm{O}_{26}$.

The findings of this study, that even though a large number of antigenic types are responsible for infection, some $\mathbf{O}$ groups are isolated from infections more frequently than others, is in agreement with the original work by Perch and the later study by Lányi. At present there is no evidence to show whether these serotypes are more pathogenic or just more frequent than others.

There is some doubt whether Proteus infections arise as a result of cross infection from local reservoirs or by autoinfection from the patient's intestines, particularly with regard to infections of the urinary tract. Kippax (1957) showed that infections in a male urological ward were due to spread from a persistent local reservoir. Krikler (1953), using antisera, and Story (1954) using the Dienes test and biochemical reactions, found, however, that urinary infections were due to autoinfection. The present study also shows a high incidence of autoinfection amongst patients with urinary tract infections. In 31 of $51(61 \%)$ of cases, organisms of identical serotype and Dienes test type could be isolated from both urine and faeces.

The wide distribution of serotypes within a ward or ward block and the low frequency with which serologically identical organisms were found in the same ward shows that cross infection from persistent reservoirs within the wards is infrequent.

The possibility that cross infection occurred from persistent reservoirs within the hospital rather than from individual wards was investigated. Dienes tests carried out on serologically identical organisms isolated from different wards showed that a large number of Dienes types could be recognized and, therefore, that in general cross infection from persistent hospital reservoirs was not responsible for the spread of this organism. There were, however, some cases where hospital reservoirs could have been responsible. The wide distribution of Dienes identical strains of serotypes $\mathrm{O}_{28} \mathrm{H}_{2}$ and $\mathrm{O}_{3} \mathrm{H}_{1}$ amongst urinary infections and $\mathrm{O}_{30} \mathrm{H}_{2}$ amongst wound infections was probably due to spread from common reservoirs.

It would, therefore, seem most probable that both auto- and cross infection play a part in the spread of Proteus and that possibly under certain circumstances one mode of spread predominates.

The results obtained from the 800 tests on a panel of 41 serotyped strains once again raises serious doubts about the absolute reliability of the Dienes test when carried out on random organisms. These results, which confirm those of previous workers (Krikler, 1953; Story, 1954), show that negative Dienes reactions among random strains are rare $(16 / 800$ or $2 \%)$. In view of the five false negative results obtained it would seem that when comparing Dienes reactions on random strains it is only possible to say that a positive Dienes test shows the organisms to be different. The results of Dienes tests on the pairs of organisms from urine and faeces also showed a high incidence of false negative results (13 of 24 or $54 \%$ ). In both groups there was a high incidence of shared $\mathrm{H}$ antigens amongst organisms giving a false negative Dienes reaction. In spite of these results when the Dienes test is carried out on strains 
that are antigenically identical it is of great value in further dividing a particular serotype and it is clear that only by combining serology and the Dienes test can reliable results be obtained.

I wish to thank Dr Hakan Gnarpe, University of Uppsala, Sweden, for providing the standard strains, Dr J. D. Williams, Dudley Road Hospital, Birmingham, for his invaluable advice and help, and $\operatorname{Dr} \mathrm{A}$. L. Woolf for his encouragement.

The organisms used in this study were isolated from patients in Dudley Road Hospital during 1966 and 1967. I am indebted to Dr J. D. Williams and the staff of the Bacteriology Department for providing these organisms and the ward staff for collection of the faecal specimens.

\section{REFERENCES}

Ayliffe, G. A. J., Lowbury, E. J. L., Hamilton, J. G., Small, J. M., Asheshov, E. A., and Parker, M. T. (1965). Lancet, 2, 365.

Barber, M., and Waterworth, P. M. (1964). J. clin. Path., 17, 69. Belyavin, G. (1951). J. gen. Microbiol., 5, 197.

- Miles, E. M., and Miles, A. A. (1951). Ibid., 5, 178.

Brooke, M. S. (1951). Acta path. microbiol. scand., 28, 313 and 328.
Cook, G. T. (1948). J. Path. Bact., 60, 171.

Dienes, L. (1946). Proc. Soc. exp. Biol. (N.Y.), 63, 265.

- (1947). Ibid., 66, 97.

Edwards, P. R., and Fife, M. A. (1952). J. infect. Dis., $91,92$.

- (1955). J. Bact., i0, 382.

Elek, S. D. (1948). J. Path. Bact., 60, 183.

Finland, M. (1960). New Engl. J. Med., 263, 207.

France, D. R., and Markham, N. P. (1968). J. clin. Path., 21, 97.

Gillies, R. R., and Govan, J. R. W. (1966). J. Path. Bact., 91, 339.

Habs, I. (1957). Z. Hyg. Infekt.-Kr., 144, 218.

Hauser, G. (1885). Ueber Fäulnissbacterien. Vogel, Leipzig.

Huang, C. T. (1966). J. clin. Path., 19, 438.

Kauffmann, F. (1949). Acta path. microbiol. scand., 26, 381.

(1966). The Bacteriology of Enterobacteriaceae, 3rd ed. Munks gaard, Copenhagen.

_, and Perch, B. (1947). Acta path. microbiol. scand., 24, 135

Kippax, P. W. (1957). J. clin. Path., 10, 211.

Krikler, M. S. (1953). Ph.D. Thesis, London University.

McCabe, W. R., and Jackson, G. C. (1962). Arch. intern. Med., 110 847 and 856.

Lányi, B. (1956). Acta microbiol. Acad. Sci. hung., 3, 417.

Pavlatou, M., Hassikou-Kaklamani, E., and Zankioti, M. (1965) Ann. Inst. Pasteur, 108, 402

Perch, B. (1948). Acta path. microbiol. scand., 25, 703.

Percival, A., Brumfitt, W., and de Louvois, J. (1964). Lancet, 2, 1027 డ్

Story, P. (1954). J. Path. Bact., 68, 55.

Turck, M., and Petersdorf, R. G. (1962). J. clin. Invest., 41, 1760.

Wahba, A. H. (1965). Brit. med. J., 1, 86.

Ujváry, G. (1958). Zbl. Bakt., l. Abt. Orig., 170, 394. 